tuberculomas, a CT study. Br J Radiology $53: 935,1980$

4. Cornell SH, Christie JH, Chiu CL, Lyon LW : Computerized axial tomography of the cerebral ventricles and subarachnoid spaces. Am J Radiology 124 : 186,1975

5. Hounsfield GN : Computerized transverse axial scanning (tomography)-description of system, Part I. Br J Radiology 46: 1016, 1973

6. Houser OW, Smith JB, Gomez MR, Baker HL : Evaluation of intracranial disorders ln children by computerized transaxial tomography--A preliminary report. Neurology $25: 607,1975$

7. Kazner E, Grumme TH, Aulich A : Axial Computerized Tomography in Neuropediatric Diseases, Cranial Computerized Tomo- graphy pp 410-414. Springer-Verlag Berlin Heidelberg, New York, 1976

8. Meese W, Lanksch W, Wende S : Diagnosis and post-operative follow-up studies in infantile hydrocephalus using computerized tomography. Cranial Computerized Tomography, p 424-429 Ibid

9. Naidich T, Epstein F, Kricheff II, Lin JP : Computerized Axial Tomography in the hydrocephalic child. Neuroradiology 5: 283, 1975

10, Paxton R, Ambrose $\mathrm{J}: \mathrm{LMI}$ scanner, A brief revief of the first 650 patients. Amer J Radiology 47 : 530, 1974

11. Rao IM, Goulatia RK, Bhargava S : CT analysis of first 525 patients. Neurology India $28: 77,1980$

\title{
Research Proposals on Diarrhoeal Diseases
}

The WHO Diarrhoeal Diseases Control Programme is undertaking a global research programme and invites scientists to submit research proposals in three main fields ;

1. Acute bacterial enteric infections. Organisms included in the programme are Vibrio cholerae 01 and related vibrios, $V$. parahaemolyticus, Escherichia coli, Campylobacter jejuri, Salmonella (including S. typhi), Shigella, and Yersinia enterocolitica.

2. Acute viral diarrhoeas. Viruses to be studied include primarily rotaviruses, and also the Norwalk and Norwalk-like agents, adenoviruses, coronaviruses, caliciviruses, and other smooth or rough, small, spherical viruses.
3. Drug development and management of acute diarrhoea, Areas to receive highest priority include (a) the improvement and simplification of techniques for rehydration therapy of acute diarrhoeas; (b) the study of interactions between acute diarrhoeal diseases and the nutrilional status of the host; and (c) the development and clinical testing of both new and existing drugs.

In 1981, in general, contracts up to US $\$ 25000$ per annum and per project will be awarded. Investigators wishing to receive support should submit a letter briefly describing their past experience and the objectives and outline of their proposed project to: The Programme Manager, Diarrhoeal Diseases Control Programme. World Health Organization, 1211 Geneva 27, Switzerland. 